\title{
A Pilot Study of Selected Health Biomarkers in Cod Gadus morhua L. from the Southern Baltic
}

\author{
Joanna Danuta Borucinska ${ }^{1}$, Dorota Morka ${ }^{2 *}$ \\ ${ }^{1}$ Department of Biology, University of Hartford \\ 200 Bloomfield Ave., West Hartford, CT 06117, USA \\ ${ }^{2}$ Department of Mathematics and Natural Sciences, Faculty of Biology and Environmental Protection \\ Pomeranian University in Slupsk, \\ Arciszewskiego 22b, 76-200 Slupsk, Poland
}

Received: 23 February 2015

Accepted: 21 October 2015

\begin{abstract}
The International Council for the Exploration of the Sea (ICES) listed the cod Gadus morhua as one of the target species for environmental biomonitoring in the Baltic, but only limited data on morphological biomarkers in this fish have been published so far. This pilot study examined cod tissues for the presence of selected biomarkers that have been studied in other target fish species for this region: flounder Platichthys flesus, herring Clupea harengus, and eelpout Zoarces viviparus. Twenty cod were collected in May 2012 off the Polish coast near Ustka. The biomarkers studied included condition factor, macroscopic lesions, morphometry of hepatic and splenic melanomacrophages, ovarian follicular atresia, and histopathology of spleen, liver, and gonads. All fish appeared in good body condition and had no macroscopic lesions except for one with multifocal dermal ulcers. Microscopic lesions were present in all fish, and included biliary myxozoanosis, ovarian microsporidiosis, larval nematodes compatible with Anisakidae, one case of intravascular trematodiasis, necrocentric granulomas, mild inflammatory and toxicopathic hepatocellular lesions, and marked accumulations of splenic melanomacrophages. This pilot study expands the types of microscopic lesions that have been documented as part of biomonitoring efforts in Baltic cod.
\end{abstract}

Keywords: Baltic, bioindicators, cod, Gadus morhua, melanomacrophages

\section{Introduction}

The Baltic Sea has been historically affected by high levels of industrial and warfare-generated pollution with corresponding high levels of pollutants in tissues of invertebrates and flatfish [1-3], and in pelagic predatory fish [4-6], including the Baltic cod [7].

*e-mail: dorota.morka@gmail.com
Biomarkers are functional measures of exposure to environmental stress that are manifested in plants and animals. Biomarkers can be expressed at any level of biological organization and have been used in biomonitoring of health and robustness of aquatic organisms, but also, indirectly, to study the health of the ecosystem itself $[8,9]$. Data in this study were collected at two levels of biological organization: organismal (condition factor, macroscopic lesions) and cellular/tissue level (histopathology). Condition factor (CF) has been employed regularly in fish studies as an 
integrative biomarker [10], and when combined with histopathological biomarkers, it can provide data on a cumulative effect of endogenous and exogenous stressors [11]. Histopathological biomarkers have been linked to exposure to specific stress factors, or were shown as less specific but sensitive markers of poor environmental quality. In the latter group, the melanomacrophage cells (MMC) and hepatic and gonadal histopathology have been commonly used in fish [11, 12].

The application of MMC as biomarkers has been reviewed previously [13]. Historically, MMC have been considered as reliable indicators of exposure to sediments contaminated with organics or low dissolved oxygen, and are reportedly more numerous in fish from contaminated sites [14].

It has been widely accepted that many environmental contaminants can have a direct or indirect negative impact on reproduction [15]. The gonadal biomarkers of environmental stress include the level of ovarian follicular atresia, ovotestes, and testicular degeneration all of which can also occur as part of normal physiological processes in fish [16, 17].

The cod Gadus morhua L. is a cold-water predator that is one of the EU's most economically important fish species due to its value for human consumption [18]. Health data from farmed and wild cod in the Atlantic include bacterial diseases, most importantly classical vibriosis [19] and francisellosis [20]. In addition, numerous parasites, including larval Anisakid nematodes, have been reported from cod within the Atlantic and European waters [21]. Some of the above pathogens have a zoonotic potential. Although parasite assemblages have been described in Baltic cod [22, 23], only limited health data have been published for Baltic cod [23, 24]. Based on its biological characteristics, i.e., top predatory position [18], documented high tissue levels of industrial pollutants [7], and cytotoxic and genotoxic changes [25, 26], cod has been listed as a sentinel/bioindicatory species of the Baltic [27]. Additionally, knowledge on the health status of the Baltic cod is important because, being a commercially harvested species, it has a high economic value but also could constitute a health hazard when consumed by humans [28].

The aim of this study was to collect pilot data on selected morphometric and morphological biomarkers from Baltic cod to expand data on histopathological bioindicators of environmental quality in this fish species.

\section{Materials and Methods}

Legal-sized cod were collected by hook and line by sports fisherman in May 2012. Twenty fish, including thirteen females and seven males, were collected within $50 \mathrm{~km}$ off the Polish Baltic coast near the town of Ustka. The fish were sacrificed immediately following collection by blunt head trauma and autopsies were performed. The gender of each fish was determined, and total length (TL), wet body weight (BW), and all external and internal
Table 1. Field data for cod, including morphometry and macroscopic lesions.

\begin{tabular}{|c|c|c|c|c|c|}
\hline $\begin{array}{l}\text { Fish } \\
\text { number }\end{array}$ & Sex & $\mathrm{BW}(\mathrm{g})$ & $\begin{array}{c}\mathrm{BL} \\
(\mathrm{cm})\end{array}$ & $\mathrm{CF}$ & $\begin{array}{c}\text { Macroscopic } \\
\text { lesions }\end{array}$ \\
\hline 1 & F & 590 & 39 & 1.00 & Ns $1^{*}$ \\
\hline 2 & F & 990 & 45 & 1.09 & Nsl \\
\hline 3 & $\mathrm{~F}$ & 1190 & 46 & 1.22 & Nsl \\
\hline 4 & $\mathrm{~F}$ & 690 & 41 & 1.00 & Nsl \\
\hline 5 & M & 1190 & 48 & 1.08 & Nsl \\
\hline 6 & $\mathrm{~F}$ & 890 & 42 & 1.20 & Nsl \\
\hline 7 & $\mathrm{M}$ & 990 & 47 & 0.95 & Nsl \\
\hline 8 & F & 1180 & 43 & 1.48 & Nsl \\
\hline 9 & $\mathrm{~F}$ & 750 & 40 & 1.17 & Nsl \\
\hline 10 & M & 990 & 44 & 1.16 & Nsl \\
\hline 11 & $\mathrm{~F}$ & 1390 & 52 & 0.99 & $\begin{array}{c}\text { Multifocal } \\
\text { dermal ulcers }\end{array}$ \\
\hline 12 & $\mathrm{~F}$ & 690 & 39 & 1.16 & Nsl \\
\hline 13 & $\mathrm{~F}$ & 1290 & 49 & 1.10 & Nsl \\
\hline 14 & $\mathrm{~F}$ & 1050 & 50 & 0.84 & Nsl \\
\hline 15 & $\mathrm{~F}$ & 1250 & 49 & 1.06 & Nsl \\
\hline 16 & M & 690 & 41 & 1.00 & Nsl \\
\hline 17 & M & 590 & 40 & 0.92 & Nsl \\
\hline 18 & $\mathrm{~F}$ & 990 & 48 & 0.90 & Nsl \\
\hline 19 & $\mathrm{M}$ & 640 & 39 & 1.07 & Nsl \\
\hline 20 & M & 790 & 42 & 1.07 & Nsl \\
\hline
\end{tabular}

Ns1*: no significant lesions

macroscopic lesions were recorded. Representative samples from organs with macroscopic lesions, and from spleen (one midsection), liver (one midsection of the right lobe), testes (one transverse mid-organ section), and ovary (three representative sections with the largest follicles) were collected into $10 \%$ buffered formalin. These samples were processed routinely for paraffin embedding, sectioned at 4-5 $\mu \mathrm{m}$, stained with hematoxylin and eosin H\&E, permanently mounted on glass slides using standard histological techniques, and examined by bright-field microscopy. In addition, special stains were used on selected sections to detect bacteria (Z-N acid fast and Tworth's stains), microsporidia (Giemsa), fungi (Grocott's), and fibrosis (trichrome) [29]. Categories of histological lesions were used as described previously by the International Council for the Exploration of the Sea (ICES) monitoring techniques [11, 30].

Gonadal staging was done according to Goodbred et al. [31], and atretic follicles were counted in the entire ovarian section using a 10x objective. The level of atresia was reported as the average number of atretic follicles per surface area at 10x objective equal to $2 \mathrm{~mm}^{2}$. The mean 
Table 2. Types of microscopic lesions with percentage of cod affected.

\begin{tabular}{|c|c|c|c|c|}
\hline & Lesion Categories & Lesion & & $\%$ affected \\
\hline 0 & No anomaly detected & & & 0 \\
\hline \multirow{14}{*}{\multicolumn{2}{|c|}{ Non-specific lesion }} & \multirow[t]{4}{*}{ Inflammatory change } & Dermal ulcers & 5 \\
\hline & & & Hepatocellular necrosis & 65 \\
\hline & & & Necrocentric granulomas liver/mesentery/spleen/ovary & 30 \\
\hline & & & Pericholangitis & 30 \\
\hline & & \multirow[t]{2}{*}{ Degenerative change } & Testicular degeneration/germ cell syncytia & 29 \\
\hline & & & Ovarian follicular atresia & 92 \\
\hline & & \multirow[t]{2}{*}{ Proliferative change } & Peribiliary fibrosis & 45 \\
\hline & & & Biliary hyperplasia & 15 \\
\hline & & Marked MMC aggregates & Spleen & 75 \\
\hline & & Lipidosis & $\begin{array}{l}\text { Hepatocellular lipidosis } \\
\text { Hepatocellular fatty change }\end{array}$ & $\begin{array}{l}90 \\
25\end{array}$ \\
\hline & & \multirow[t]{4}{*}{ Parasites } & $\begin{array}{c}\text { Anisakid larvae granulomas } \\
\text { Liver and mesentery }\end{array}$ & 15 \\
\hline & & & trematodiasis/liver & 5 \\
\hline & & & Biliary myxozoanosis & 30 \\
\hline & & & Ovarian microsporidiosis & 10 \\
\hline & $\begin{array}{l}\text { Early toxicopathic } \\
\text { hges }\end{array}$ & & $\begin{array}{l}\text { Hepatocellular megalocytosis } \\
\text { Peliosis hepatis }\end{array}$ & $\begin{array}{l}60 \\
20\end{array}$ \\
\hline
\end{tabular}

diameter of the largest follicles was calculated based on the 20 largest follicles measured.

Condition factor CF has been calculated based on the formula applied by Drevnick et al. [32], where:

$$
\mathrm{CF}=[100,000 \times \mathrm{BW} \mathrm{g}] /[\mathrm{TL} \mathrm{mm}]^{3}
$$

Morphological types of hepatic and splenic MMC were described, and their pigments were identified with Pearl's blue [29]. Morphometric analysis of hepatic MMC was performed on 20 arbitrarily selected high-power fields HPF (40x objective) to count the number of MMC per HPF; these were used to calculate the mean number of MMC in one HPF for each fish. In the spleen, the MMC analysis was done as above, except due to the MMC morphology, i.e., curvilinear shape and confluence, the average for the $\%$ of splenic surface occupied by MMC in one HPF section was calculated.

All measurements in the ovary, liver and spleen were done with a digital measuring system (Spot Insight TM Diagnostic Instruments Inc., Sterling Heights MI, USA) mounted on an Olympus BX41 microscope (Olympus America, Melville, NY, USA).

\section{Results}

Field data for the collected fish are shown in Table 1. The mean BL for females was $44.85 \mathrm{~cm}$ (range 39-52) and for males $43 \mathrm{~cm}$ (range 39-48). The mean BW for females was $995 \mathrm{~g}$ (range 590-1390) and for males $840 \mathrm{~g}$ (range 590-1190). Mean CF for all fish was 1.065; mean for females was 1.09 (range 0.84-1.48), and for males 1.04 (range 0.92-1.16). All fish appeared in good body condition and macroscopic lesions were found only in fish No. 11; these consisted of severe multifocal dermal ulcers (Table 1). Microscopic lesions were found in all fish, and fell into the categories of 1 . non-specific and 2 . early toxicopathic/non neoplastic $[11,30]$. The lesions are listed in Table 2, which also provides the percentage of fish affected by each lesion.

The following is a description of histological findings with the percentage of fish affected provided. In the liver, microvacuolation compatible with glycogen storage was present in $43 \%$ of male and $31 \%$ of female fish. Hepatocellular macrovacuolation compatible with lipid storage was present in $90 \%$ of fish, but in $29 \%$ of males and $23 \%$ of females it was severe enough to be compatible with fatty change. Hepatocellular anisocytosis and megalocytosis were found in $60 \%$ of fish $(29 \%$ in male and $77 \%$ in female) (Fig. 1). Minimal multifocal necrosis was found in $65 \%$ of fish $(71 \%$ of males and $62 \%$ of females). In six cases the necrotic hepatocytes had intracellular organisms compatible with protista, but their identity could not be established. In addition, there was one case of peliosis (Fig. 2), two fish had necrocentric granulomas (Fig. 3), two livers harbored parasitic granulomas with anisakid nematode larvae, 
and one fish had severe necrotizing hepatitis associated with a digenean compatible with a trematode located within a necrotic blood vessel (Fig. 4). The intrahepatic biliary system had intraepithelial and coelozoic Myxozoa associated with minimal pericholangitis and peribiliary fibrosis in $30 \%$, and biliary hyperplasia in $15 \%$ of fish (Fig. 5). In the mesentery parasitic granulomas with Anisakid compatible larvae and a necrocentric granuloma

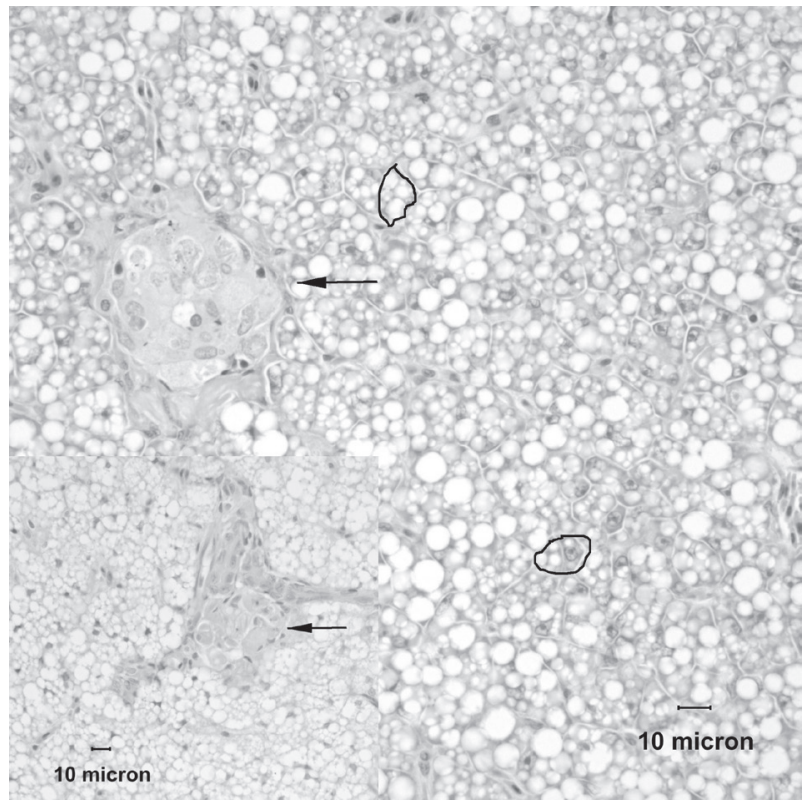

Fig. 1. Liver of female cod in mid-late vitellogenesis. Hepatocytes have basophilic cytoplasm with macrovacuolation; Marked anisocytosis and megalocytosis (examples of megalocytes outlined in black) and a focus of MMC $(\rightarrow)$ associated with necrotic cells; H\&E.

Insert: liver of male cod with microvacuolated hepatocytes with marginated granular eosinophilic cytoplasm; MMC aggregate $(\rightarrow)$; H\&E.

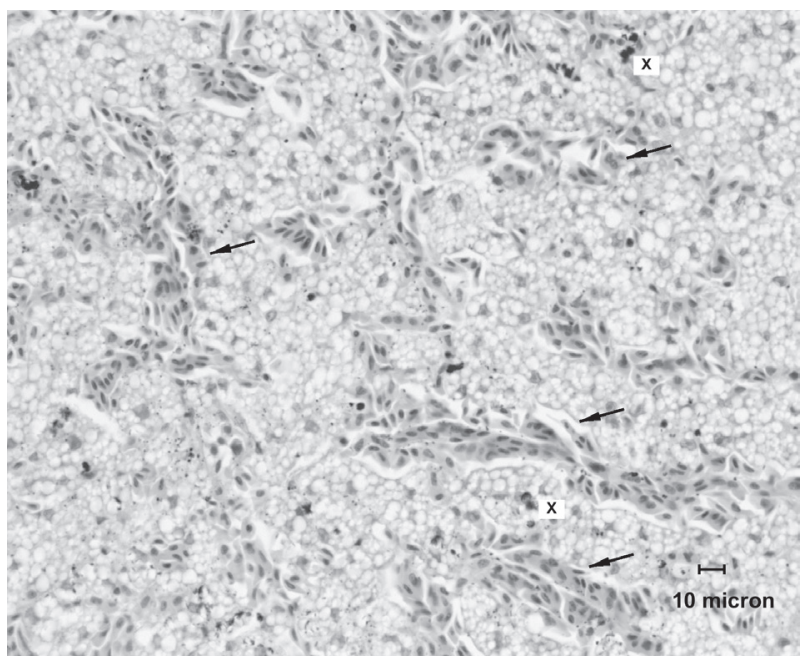

Fig. 2. Baltic cod, liver with focal expansion of blood-filled sinusoids $(\rightarrow)$ compatible with peliosis hepatis; rare MMC are marked with X; H\&E. were found in 1 fish each (5\% of fish). In the spleen, necrocentric granulomas were present in $5 \%$ of fish. The ovary had granulomas with Microsporidia in 10\% (Fig. 6) and necrocentric granulomas in $15 \%$ of fish, and moderate numbers of atretic follicles in most females (Fig. 7, Table 3 ). The testes had minimal degenerative changes in the form of condensed, apparently apoptotic cells (Fig. 8), and scattered multinucleated spermatids in $29 \%$ of males (Table 3).

Special stains confirmed minimal peribiliary fibrosis, $\mathrm{G}^{+}$Microsporidia within ovaries, and very few $\mathrm{G}^{-}$bacteria in necrocentric granulomas (Fig. 9); stains for acid-

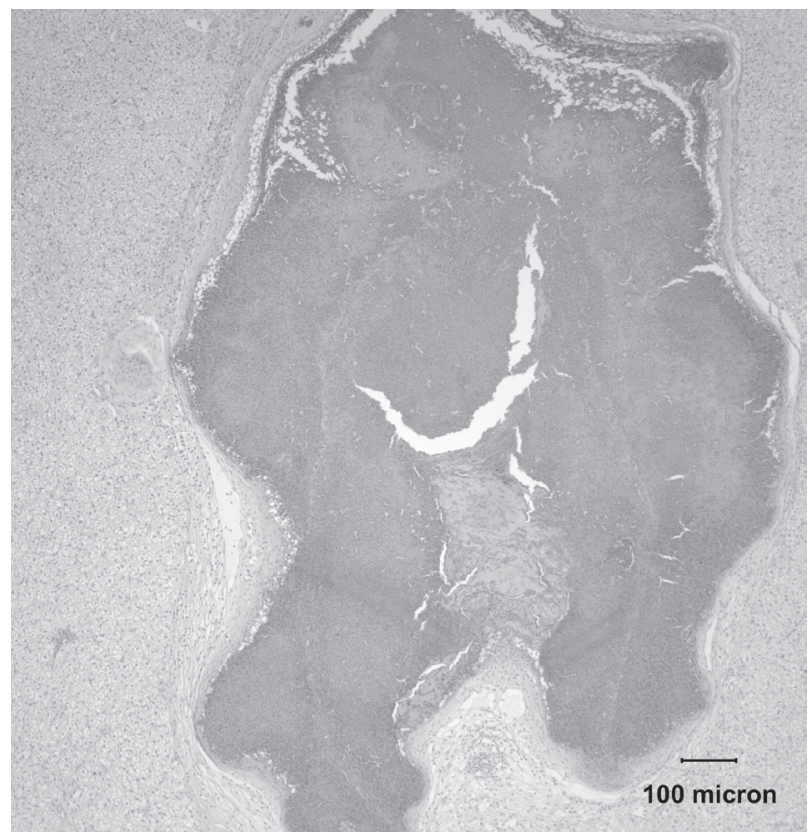

Fig. 3. Baltic cod, liver with large necrocentric granuloma; H\&E.

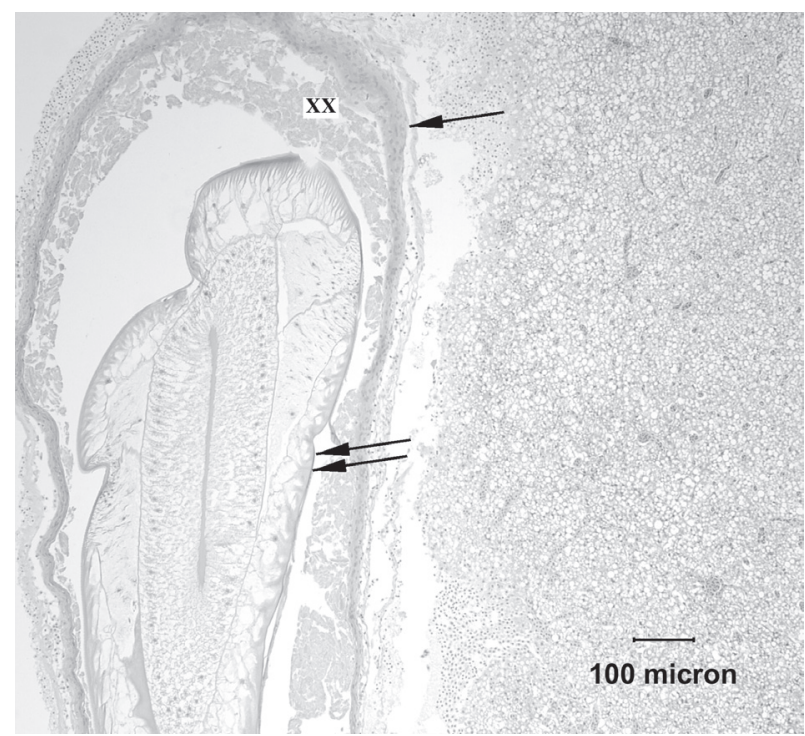

Fig. 4. Baltic cod, liver with a trematode (double $\rightarrow$ ) within an arteriole; the vascular media is thinned $(\rightarrow)$ and the intima is diffusely necrotic and lined by fibrin (XX); H\&E. 
fast bacteria or fungi were negative in all necrocentric granulomas examined.

Among females, 23\% were previtellogenic, 8\% early vitellogenic, and $69 \%$ mid-late vitellogenic (Table 3 ). The mean diameter of the largest follicles in previtellogenic fish was $145 \mu$ (range 117-191) and in vitellogenic 432 $\mu$ (range 336-554). All but one female fish had atretic follicles; the mean number of atretic follicles per $2 \mathrm{~mm}^{2}$ in previtellogenic fish was 0.19 (range 0-0.73) and 1.9 for vitellogenic (range 0.33-4.27). There was no apparent

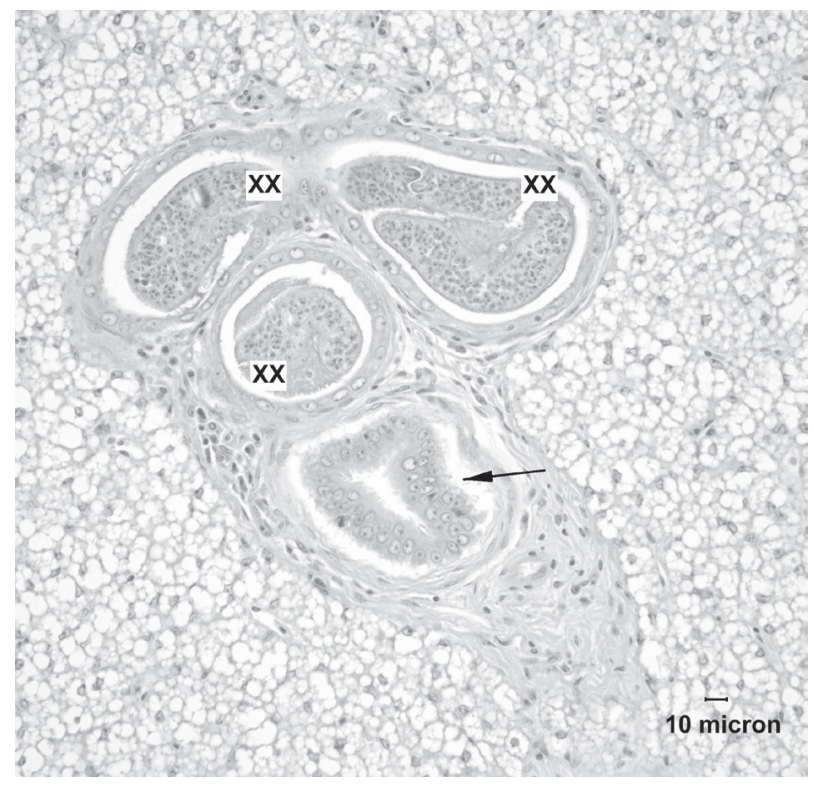

Fig. 5. Baltic cod liver with several intrabiliary plasmodia of a myxozoan parasite $(\mathrm{XX}) ;(\rightarrow)$ points to a hyperplastic bile duct surrounded by minimal pericholangitis and peribiliary fibrosis; $\mathrm{H} \& \mathrm{E}$.

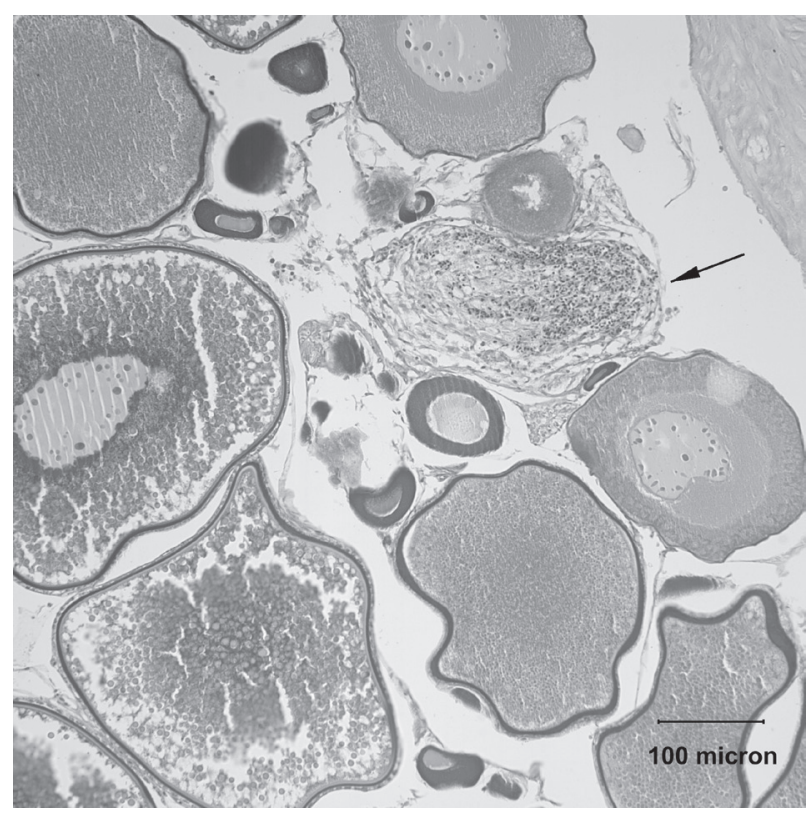

Fig. 6. Baltic cod, mid-late vitellogenic ovary with a granuloma harboring numerous $\mathrm{G}+$ microsporidia $\rightarrow$ ); Tworth's stain. association of atresia with the total number of lesions in the organs examined, nor with the presence of toxicopathic lesions or fish size (Table 3). Ovarian follicular nuclear vacuolation/collapse and cytoplasmic shrinking were noted in three fish, but not classified as degenerative changes (see discussion). All male fish were mid-late spermatogenic and $29 \%$ had minimal degenerative changes in their testes as described above (Table 3 ).

Hepatic MMC were only present in $20 \%$ of fish. The hepatic MMC consisted of singular or small groups (2-4) of cells with granular black pigment or organized MMC, i.e., large cells with granular golden pigment contained within thin collagenous capsules (Figs 1, 2). The most prominent organized MMC were in the fish with hepatic

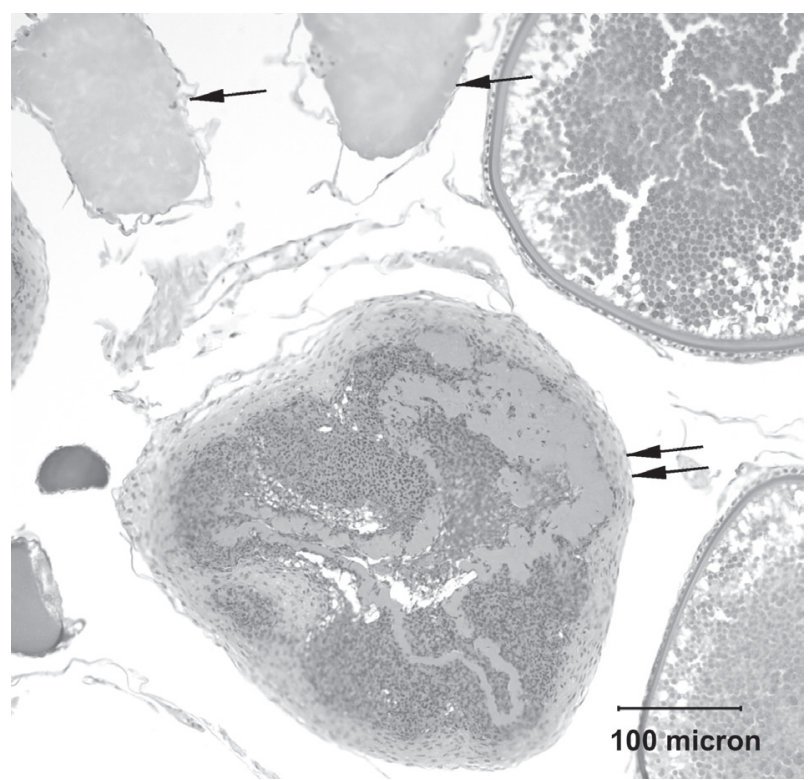

Fig. 7. Baltic cod, mid-late vitellogenic ovary with a necrocentric granuloma (double $\rightarrow$ ) apparently within a necrotic follicle and adjacent remnants of atretic follicles $(\rightarrow)$; H\&E.

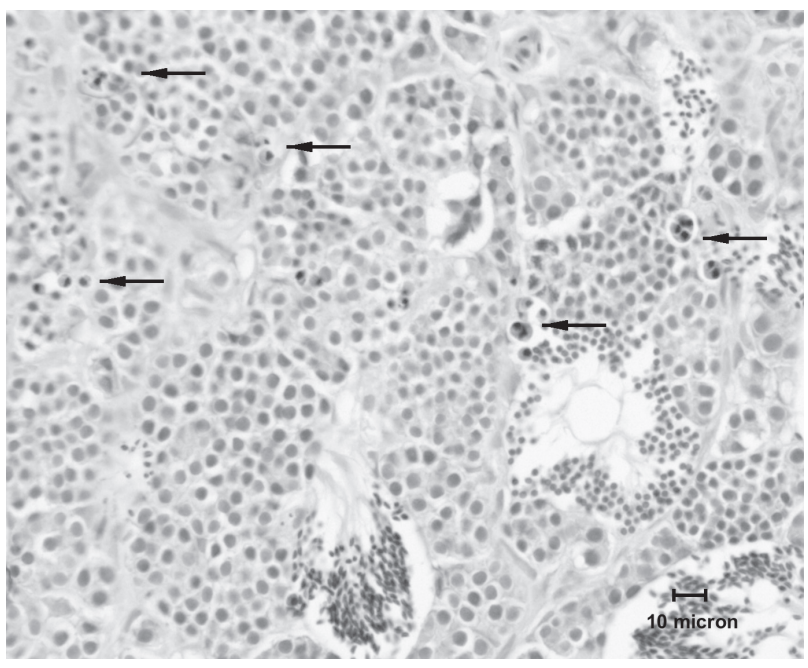

Fig. 8. Baltic cod testes; randomly scattered foci of apoptotic germinal cells $(\rightarrow)$; H\&E. 
Table 3. Gonad data, including stage, levels of atresia, morphometry of follicles, lesions in gonads, and total numbers of lesions in all organs examined in each fish.

\begin{tabular}{|c|c|c|c|c|c|}
\hline Fish & Gonadal stage & $\begin{array}{l}\text { Number atretic } \$ \\
\qquad 2 \mathrm{~mm}^{2}\end{array}$ & $\begin{array}{c}\text { Largest } \\
\text { Follicle } \\
\quad \mathrm{x} \mu\end{array}$ & Lesions in gonads & Total lesions \\
\hline 1 & previtellogenic & 0.13 & 127 & $\mathrm{Ns}{ }^{\$ \$}$ & 2 \\
\hline 2 & $\mathrm{mid} /$ late vitellogenic & 2.27 & 450 & Nsl & $2^{*}$ \\
\hline 3 & early vitellogenic & 2.73 & 461 & Nsl & $5^{*}$ \\
\hline 4 & $\mathrm{mid} /$ late vitellogenic & 1.40 & 336 & $\begin{array}{c}\text { Necrocentric granuloma } \\
\text { Nuclear vacuolation/collapse }\end{array}$ & 2 \\
\hline 5 & mid-late spermatogenic & - & NA & Nsl & 4 \\
\hline 6 & $\mathrm{mid} /$ late vitellogenic & 4.27 & 360 & Nuclear vacuolation/collapse & $5^{*}$ \\
\hline 7 & mid-late spermatogenic & - & & Nsl & $5^{*}$ \\
\hline 8 & $\mathrm{mid} /$ late vitellogenic & 1.47 & 375 & Granuloma, Microsporidia & $3^{*}$ \\
\hline 9 & $\mathrm{mid} /$ late vitellogenic & 0.53 & 554 & Nsl & $2^{*}$ \\
\hline 10 & mid spermatogenic & - & NA & $\begin{array}{c}\text { Apoptosis } \\
\text { Multinuclear spermatids }\end{array}$ & $4^{*}$ \\
\hline 11 & late vitellogenic & 0.33 & 472 & Nsl & $2^{*}$ \\
\hline 12 & $\mathrm{mid} /$ late vitellogenic & 0.80 & 394 & Granuloma, Microsporidia & $5^{*}$ \\
\hline 13 & previtellogenic & 0.73 & 191 & Nuclear vacuolation & 4 \\
\hline 14 & $\mathrm{mid} /$ late vitellogenic & 2.73 & 400 & Nsl & $1^{*}$ \\
\hline 15 & mid vitellogenic & 2.47 & 513 & Necrocentric granulomas & $3^{*}$ \\
\hline 16 & mid spermatogenic & - & NA & $\begin{array}{c}\text { Apoptosis } \\
\text { Multinuclear spermatids }\end{array}$ & 1 \\
\hline 17 & mid spermatogenic & - & NA & Nsl & 2 \\
\hline 18 & previtellogenic & 0.00 & 117 & Necrocentric granuloma & 6 \\
\hline 19 & mid spermatogenic & - & NA & Nsl & 5 \\
\hline 20 & mid spermatogenic & - & NA & Nsl & $5^{*}$ \\
\hline
\end{tabular}

s: average based on all ovarian sections examined at 10x objective

ss: no significant lesions

*: denotes the presence of early toxicopathic category of lesions

trematodiasis. Due to the very small numbers of MMC in the livers, the percentage of liver surface occupied by them in histological sections was not calculated. The average number of hepatic MMC per HPF in the four fish ranged from 0.05-4.3. In the spleen, MMC were seen as sporadic clusters of MMC with black, granular pigment, and/or curvilinear aggregates of perisinusoidal cells that followed the outlines of red pulp sinusoids (Fig. 10). The latter contained both granular black and gold-brown pigment.

Except for fish Nos. 4, 5, 6, 7, and 19, which had very infrequent MMC (range $0-7.6 \%$ of splenic surface occupied), all remaining fish had high or very high values for MMC, with the average percentage of splenic surface occupied equal to 36.89 (range 19.1-56.9\%; Table 4). No apparent association between the MMC values and any other biomarkers studied, including size of fish, was present. The pigments in both splenic and hepatic MMC did not contain iron (except one cluster in one fish) on Pearl's blue staining and thus were classified as ceroid (golden brown) and melanin (black).

\section{Discussion}

There is a wide consensus on the need for monitoring marine waters to understand the impact of changing environmental parameters on the health of aquatic life and, by extension, human health [5, 32-34]. Accordingly, numerous integrative biomonitoring tools have been employed worldwide to assess ecological integrity of marine ecosystems [35]. In the Baltic, a multinational program with the goals to measure, monitor, and control environmental degradation has been outlined in the EU- 
funded Biological Effects of Environmental Pollution (BEEP) project as outlined by the ICES Baltic Committee [27] that adopted biomonitoring standards and procedures $[11,36-40]$, several of which were used in the present study. The BEEP project resulted in data on high levels of organic pollutants and abnormal physiological parameters in coastal fish and bivalves [ 40-45], cytotoxic and genotoxic changes in fish $[25,26]$, and on morphological changes in tissues of fish $[46,47]$. The latter were documented in several species of fish, including the flounder Platichthys flesus $[46,48]$ and the Baltic eelpout Zoarces viviparus [49]. Although the cod Gadus morhua has been named by ICES as one of the target species for environmental biomonitoring in the Baltic [50], to the best of our knowledge only limited data on histopathological lesions in this fish have been published so far [24]. Morphological biomarkers reported in the other target fish species for this region, the flounder Platichthys flesus, herring Clupea harengus, and eelpout Zoarces viviparus, included presence of hepatic and splenic melanomacrophages, hepatocellular cellular atypia, foci of cellular alteration, and hepatic adenomas [51]. In addition, hepatocellular degeneration was described in perch (Perca fluviatilis) and northern pike (Esox lucius) impacted by PAH along the Swedish coastline [4], and high frequencies of micronuclei, a genotoxicity marker, were found in blood erythrocytes of cod, flounder, herring (Clupea harengus), and eelpout (Zoarces viviparus) $[6,25,26]$. Historically, high levels of anthropogenic lipophilic pollutants have been reported from fish, including cod, collected along the Polish coast $[1,2,52,53]$, but histopathological descriptions are sparse [46, 48, 49]. Our study found a high prevalence of histological lesions in selected organs of all cod examined. The lesions included parasitic, early

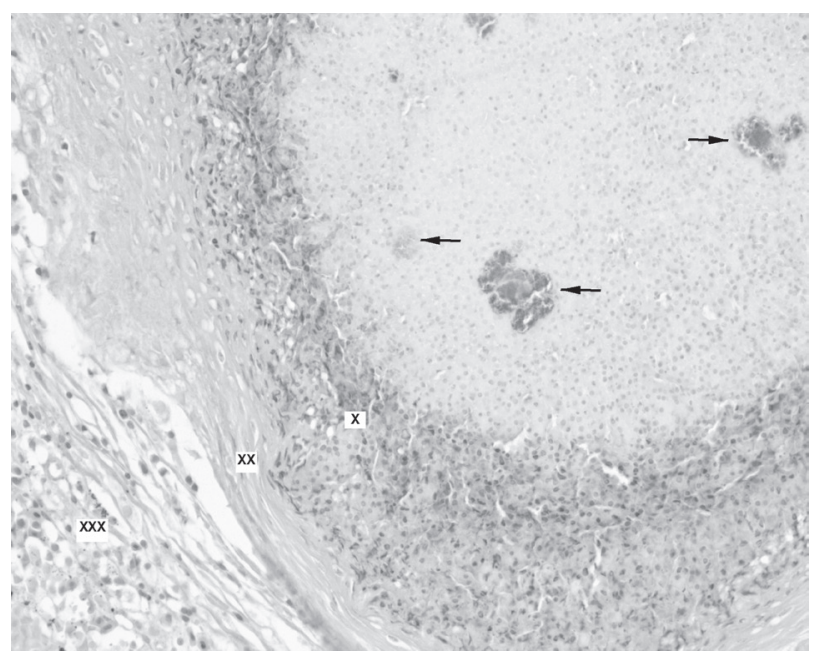

Fig. 9. Baltic cod, liver with large necrocentric granuloma with scattered colonies of G- rods $(\rightarrow)$ within the necrotic core; $\mathrm{X}$ : mononuclear cells including epithelioid macrophages surrounding the necrotic core

$\mathrm{XX}$ : fibrous capsule

XXX: peripheral edematous liver tissue with mononuclear cell infiltrates; Tworth's stain hepatocellular toxicopathic and inflammatory changes, degenerative changes in the gonads (including germ cell syncytia), moderate levels of ovarian atresia, and very high levels of splenic MMC. Interestingly, the general indicator of health, i.e., CF, was high in our study as compared to some studies as outlined below.

A study on parasites in cod from the Kieler Fiord by Möller [23] provided data on condition factors for gutted cod with body lengths between 25 and $49 \mathrm{~cm}$; the mean $\mathrm{CF}$ in this group was 0.774 , this low value due to the fact that they examined gutted fish. A study in the Atlantic by Aas et al. [28] documented differences in CF between cod from polluted vs. non-polluted sites (range 0.74-0.89 from polluted site vs. $0.93 \pm 0.06$ from reference site). In fish from our study, the two fish with severe lesions, i.e., skin ulcers and parasitic trematodiasis (albeit apparently in good body condition) had a CF value similar to the above-polluted sites, but the remaining fish from our study had a higher condition factor; this may have been partially caused by different collection times, i.e., Aas et al. [28] collected post-spawning fish in September and October. The above CF values can be compared otherwise, because the fish from both studies had similar body weight ranges $(800 \pm 450$ in Aas et al. [28]).

Skin ulcers in Atlantic cod have been reported from waters affected by aluminium works, resulting in pollution with polycyclic aromatic hydrocarbons (PAHs) [28], and with bacterial infections, including experimental mycobacteriosis [54] and natural infections with Francisella noatunensis [55]. The latter infection resulted in multisystemic necrocentric granulomas that characteristically contained very few bacteria. Although first described only from farmed cod in Norway and Sweden [20], the horizontal spread of Francisella sp. to wild cod

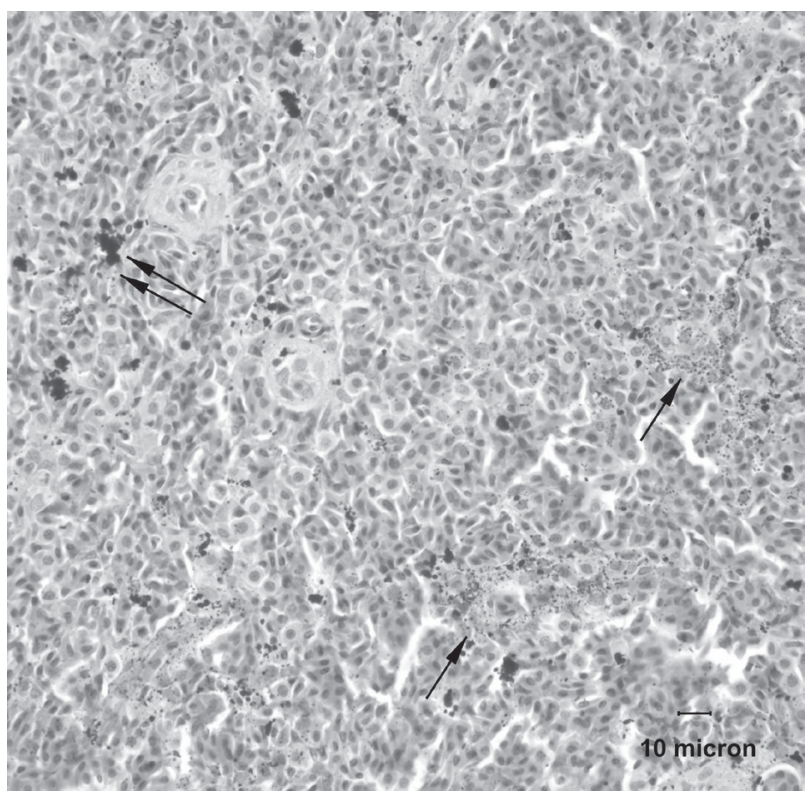

Fig. 10. Baltic cod spleen; randomly scattered foci of melanomacrophage cells MMC with black granular pigment $($ double $\rightarrow$ ) and curvilinear perisinusoidal MMC with a mix of black and fine golden brown granular pigments $(\rightarrow)$; H\&E. 
Table 4. Morphology and morphometry (\% of splenic surface occupied) of MMC in the spleens of cod with the total number of lesions in each fish.

\begin{tabular}{|c|c|c|c|c|c|c|c|}
\hline \multirow{2}{*}{ Fish number } & \multicolumn{3}{|c|}{ TYPE OF MMC } & \multicolumn{2}{|c|}{ PREDOMINANT PIGMENT } & \multirow{2}{*}{$\begin{array}{c}\% \text { SURFACE } \\
\text { MMC }\end{array}$} & \multirow{2}{*}{$\begin{array}{c}\text { Number of lesions in } \\
\text { all categories }\end{array}$} \\
\hline & $\mathrm{ENC}^{1}$ & SPORADIC & $\mathrm{PSD}^{2}$ & Melanin & Ceroid & & \\
\hline 1 & - & + & +++ & & + & 41.6 & 2 \\
\hline 2 & - & + & +++ & & + & 41.0 & 2 \\
\hline 3 & 11 & + & $+/-$ & & + & 32.4 & 5 \\
\hline 4 & - & + & - & + & & 0.2 & 2 \\
\hline 5 & - & + & - & + & & 0.0 & 4 \\
\hline 6 & - & + & - & + & & 0.0 & 5 \\
\hline 7 & - & + & - & + & & 0.2 & 5 \\
\hline 8 & 9 & + & +++ & & + & 34.9 & 3 \\
\hline 9 & 8 & + & + & + & & 33.6 & 2 \\
\hline 10 & 1 & + & + & + & & 35.7 & 4 \\
\hline 11 & - & + & +++ & + & + & 41.5 & 2 \\
\hline 12 & - & + & +++ & & + & 39.9 & 5 \\
\hline 13 & 14 & + & +++ & & + & 32.1 & 4 \\
\hline 14 & 89 & + & +++ & & + & 41.9 & 1 \\
\hline 15 & - & + & + & + & & 44.7 & 3 \\
\hline 16 & 3 & + & +++ & & + & 56.9 & 1 \\
\hline 17 & - & + & + & & + & 47.6 & 2 \\
\hline 18 & - & + & +++ & + & + & 39.7 & 6 \\
\hline 19 & 10 & + & + & + & & 7.6 & 5 \\
\hline 20 & 23 & + & + & + & & 19.1 & 5 \\
\hline
\end{tabular}

has been documented and postulated to threaten wild fish stocks [56]. Indeed, Francisella sp. has been recently identified by immunohistochemistry in liver lesions in one cod from Mecklenburg Bight in the southwestern Baltic Sea [57]. Our finding of multisystemic granulomas with no bacteria detected by acid fast or Tworth's stain (except in the visceral granulomas of fish No. 13 that contained few colonies of short $\mathrm{G}^{-}$rods) is compatible with the descriptions of chronic lesions in experimental $F$. noatunensis in cod [58]. Further studies are needed to confirm the spread of Francisella sp. in the Baltic.The fish with dermal ulcers had no necrocentric granulomas in other tissues, and the dermal ulcers were histologically negative for microorganisms. Ulcerative dermatitis from cod in the Kieler Fiord has been postulated to be associated with Vibrio sp. [22]. Mycobacteria and fungi were not detected by histological stains in the necrocentric granulomas in this study; Microsporidia-associated granulomas found by us in the ovaries were morphologically very different from the necrocentric granulomas, suggesting that the latter were not caused by Microsporidia.
Xenomas of Ichthyophonus hoferi (Plehn \& Mulsow), a Microsporidian classified previously as fungal cysts [22, 23], have been reported from the heart, liver, kidneys, spleen, and muscle in the Baltic cod. This is the first record of ovarian microsporidiasis in cod from the Baltic. Interestingly, Möller [23] reported a low CF (0.742) in a single cod with systemic microsporidiasis as compared to non-infected cod; the two female fish in our study that harbored microsporidia had CF equal to 1.16 and 1.48 , which was above the average $\mathrm{CF}$ for all female fish in our study (1.09).

Gadid fishes in the North Atlantic and the North Sea can harbor several species of biliary coelozoic Myxozoa [59]; these infections may produce biliary hyperplasia, pericholangitis, and peribiliary fibrosis [60-62]. Myxidium oviforme (Parisa) has been reported from cod in the Baltic $[22,23]$, but the associated pathology was not provided. We report biliary myxozoanosis in $30 \%$ of cod examined, and the minimal lesions of hepatocellular necrosis, pericholangitis, peribiliary fibrosis, and biliary hyperplasia present in these fish most likely represent a causal 
relationship. Similar lesions of the liver and intrahepatic biliary system have been described in myxozoanosis in eelpout (Z. viviparus) in the Baltic [49].

Our finding of anisakid-compatible nematode larvae supports data indicating that they are commonly found in the Baltic cod [23]; currently these parasites, which constitute a human health hazard, are becoming a serious problem due to increasing populations of the final host the common seal (Phoca vitulina) [63-65].

Several species of intestinal trematodes have been reported from cod in the Baltic [22, 23], and Atlantic [21, 59]. An adult hemiurid tramatode, Gonoerca macroformis, has been reported from Atlantic cod ovaries [59, 62]. To the best of our knowledge this is the first report of an intravascular, intrahepatic trematode (Dr. Ash Bullard, personal communication), although its intravascular location may be an incidental finding. Histozoic and intravascular flukes are considered potentially serious pathogens that can cause mortality both in aquaculture and in wild fish [66], which is consistent with the severity of lesions and low CF in the affected fish from this report. Metazoan parasites in herring have been proposed as biological indicators in the Baltic Sea [67], and expanded studies on parasites in cod could possibly expand the biomarker repertoire provided by this fish.

The toxicopathic lesions in this study included hepatocellular megalocytosis and peliosis; the hepatocellular fatty change found in four fish needs to be interpreted with caution due to the fact that the liver in gadoids is physiologically accumulating fat. Both hepatocellular fat and glycogen are accumulated before spawning to be used during the reproductive period. Accordingly, hepatocellular eosinophilia with minimal macrovacuolation, consistent with glycogen and fat depletion, respectively, was present in male spermatogenic fish while most female fish had cytoplasmic basophilia and macrovacuolation consistent with vitellogenesis.

The average number of atretic follicles per $2 \mathrm{~mm}^{2}$ of ovarian sections ranged from $0-4.27$. The previtellogenic ovaries had the lower values that are consistent with data from other fish species $[15,68]$. In fish No. 36 with the highest level of atresia, the percentage of atretic follicles ( $1-2 \%$ of follicles per field, data not shown) was still below $20 \%$, whose value has been postulated to be compatible with reproductive failure [68]. We found several changes in oocyte morphology, including nuclear vacuolation/ collapse and cytoplasmic shrinking, but the significance of these remains to be established by future studies because these could be artefacts created by handling and fixation.

This study found a very high level of splenic MMC in the majority of examined fish. The spleens of juvenile cod (BW around 200g) do not have MMC as has been shown in experimental infection with $F$. noatunensis [58]. The splenic perisinusoidal aggregates of MMC found in the majority of adult cod from the Baltic collected in this study support the hypothesis that splenic MMC increase with age [58], but the marked differences in their morphometric values $(0-56.9 \%$ of splenic surface occupied by MMC) indicate that environmental factors, not just age, play a role in their formation. Splenic MMC have been used previously as bioindicators of pollution in fish [14], and our study indicates that in cod the spleen is the major organ of MMC aggregation as negligible numbers of MMC were present in the livers. The major pigments in $\mathrm{MMC}$ in our fish were melanin and ceroidlipofuscin, with iron staining being negative in most of them. Accordingly, the pathogenesis of the MMC may have included inflammatory and necrotic processes with reactive oxygen species generation consistent with infectious and toxicopathic events [14].

\section{Conclusions}

Selected biomarkers of environmental quality and histopathological features of livers, spleens, and gonads are described from a small group of cod in the Baltic Sea. We found several known and new pathological features, thus our findings expand the existing data that were collected from cod for assessing environmental quality of the Baltic.

\section{Acknowledgements}

We thank captain Boleslaw Adamowicz and his crew on "Amelia" for accommodating us on a fishing cruise and the fisherman for allowing us to sample their catch; Mira Jagodzinska and the Pomeranian University in Slupsk, Poland, for technical support; and the University of Hartford and the University of Connecticut for logistical and laboratory support. This study was supported by faculty development funds and an International Travel Grant from the University of Hartford.

\section{References}

1. FALANDYSZ J., WYRZYKOWSKA B., WARZOCHA J., BARSKA I., GARBACIK-WESOŁOWSKA A., SZEFER P. Organochlorine pesticide and PCBs in perch Peca fluviatilis from the Odra/Oder River estuary, Baltic Sea. Food Chem. 87, 17, 2004.

2. DABROWSKA H., OSTASZEWSKA T., KAMASZEWSKI M., ANTONIAK A., NAPORA-RUTKOWSKI L., KOPKO O., LANG T., FRICKE N.F., LEHTONEN K.K. Histopathological, histomorphometrical, and immunohistochemical biomarkers in flounder (Platichthys flesus) from the southern Baltic Sea. Ecotoxicol Environ Safety 78, 14, 2012.

3. KREITSBERG R., TUVIKENE A., BARŠIENE J., FRICKE N.F., RYBAKOVAS A., ANDREIKÉNAITÉ L., RUMVOLT K.,VILBASTE S. Biomarkers of environmental contaminants in the coastal waters of Estonia (Baltic Sea); effects on eelpouts (Zoaerces viviparus). J Environ Monit. 9, 2298, 2012.

4. ERICSON G., LINDESJOO E., BALK L. DNA adducts and histopathological lesions in perch (Perca fluviatilis) and northern pike (Esox lucius) along a polycyclic aromatic hydrocarbon gradient on the Swedish coastline of the Baltic Sea. Can J Fish Aquat Sci. 55, 815, 1998. 
5. HANSON N., FÖRLIN L., LARSSON Ă. Evaluation of long-term biomarker data from perch (Perca fluviatilis) in the Baltic Sea suggests increasing exposure to environmental pollutants. Environ Tox Chem. 28, 364, 2009.

6. BARŠIENE J., RYBAKOVAS A., LANG T., GRYGIEL W., ANDREIKĖNAITE L., MICHAILOVAS A. Risk of environmental genotoxicity in the Baltic Sea over the period of 2009-2011 assessed by micronuclei frequencies in blood erythrocytes of flounder (Platichthys flesus), herring (Clupea harengus) and eelpout (Zoarces viviparus). Mar Environ Res. 77, 35, 2012.

7. SCHNELL S., SCHIEDECK D., SCHNEIDER R., BALK L., VUORINEN P.J., VUONTISJÄRVI H., LANG T. Some indications of contaminant effects on the Baltic cod (Gadus morhua L.). ICES Theme Session on Biological Effects Monitoring in the Baltic Sea CM 2003/M:09, 2003.

8. MEARNS A.J., REISH D.J., OSHIDA P.S., GINN T., REMPEL-HESTER M.A. Effects of pollution on marine organisms. Wat Environ Res. 83, 1789, 2011.

9. DAVIES I.M., VETHAAK A.D. Integrated marine environmental monitoring of chemicals and their effects. ICES Cooperative Research Report 315 Copenhagen, Denmark. 2012.

10. JENKINS J.A. Fish as bioindicators of ecosystem condition at the Calcasieu Estuary, Louisiana. USGS U.S. Geological Survey Open-File Report 2004-1323. Reston, Virginia 2004.

11. FEIST S.W., LANG T., STENTIFORD G.D., KÖHLER A. Biological effects of contaminants: use of liver pathology of the European flatfish dab (Limanda limanda L.) and flounder (Platichthys flesus L.) for monitoring. ICES Techniques in Marine Environmental Sciences 38, International Council for the Exploration of the Sea Copenhagen, Denmark 2004.

12. AU D.W.T. The application of histo-cytopathological biomarkers in marine pollution monitoring: a review. Mar Poll Bull. 48, 817, 2004.

13. AGIUS C., ROBERTS R.J. Melano-macrophage centres and their role in fish pathology. J Fish Dis. 26, 499, 2003.

14. FOURNIE J.W., SUMMERS J.K., COURTNEY L.A., ENGLE V.D., BLAZER V.S. Utility of splenic macrophage aggregates as an indicator of fish exposure to degraded environments. J Aquat Anim Health 13, 105, 2001.

15. CORRIERO A., ZUPA R., BELLO G., MYLONAS C.C., DEFLORIO M., GENOVESE S., BASILONE G., BUSCAINO G., BUFFA G., POUSIS C., DE METRIO G., SANTAMARIA N. Evidence that severe acute stress and starvation induce rapid atresia of ovarian vitellogenic follicles in Atlantic bluefin tuna, Thunnus thynnus (L.) (Osteichthyes: Scombridae). J Fish Dis. 34, 853, 2011.

16. BLAZER V.S. Histopathological assessment of gonadal tissue in wild fishes. Fish Physiol Bioch. 26, 85, 2002.

17. PATIŇO R., GOODBRED S.L., DRAUGELIS-DALE R., BARRY C.E., FOOTT S.J., WAINSCOTT M.R., GROSS S.T., COVAY K.J. Morphometric and histopathological parameters of gonadal development in adult common carp from contaminated and reference sites in Lake Mead, Nevada. J Aquat Anim Health 15, 55, 2003.

18. EU Project CODTRACE [home page on the internet]. www.

19. MARLOWE C., CAIPANG A., HYNES N., PUANGKAEW J., BRINCHMANN M.F., KIRON V. Intraperitoneal vaccination of Atlantic cod, Gadus morhua with heat-killed Listonella anguillarum enhances serum antibacterial activity and expression of immune response genes. Fish \& Shellfish Immunol. 24, 314, 2008.

20. OLSEN A.B., MIKALSEN J., RODE M., ALFJORDEN A., HOEL E., STRAUM-LIE K., HALDORSEN R.,
COLQUHOUN DJ. A novel systemic granulomatous inflammatory disease in farmed Atlantic cod Gadus morhua L. associated with a bacterium belonging to the genus Francisella. J Fish Dis. 29, 307, 2006.

21. PERDIGUERO-ALONSO D., MONTERO F., RAGA J.A., KOSTADINOVA A. Composition and structure of the parasite faunas of cod, Gadus morhua L. (Teleostei: Gadidae) in the North East Atlantic. Parasites \& Vectors 1, 1, 2008.

22. REIMER L.W., WALTER U. Zur Parasitierung von Gadus morhua in der südlichen Ostsee. App Parasit. 34, 181, 1993.

23. MÖLLER H. Die Parasiten des Dorsches (Gadus morhua L.) in der Kieler Förde. Berichte der Deutschen Wissenchaftlichen Kommision für Meeresforschung 24, 71, 1974.

24. MELLERGAARD S., LANG T. Diseases and parasites of Baltic cod (Gadus morhua) from the Mecklenburg Bight to the Estonian coast. ICES J Mar Sci. 56, 164, 1999.

25. RYBAKOVAS A., BARŠIENĖ J., LANG T. Environmental genotoxicity and cytotoxicity in the offshore zones of the Baltic and the North Sea. Mar Environ Res. 68, 264, 2009.

26. BARŠIENĖ J., BUTRIMAVIČIENĖ, GRYGIEL W., LANG T., MICHAILOVAS A., JAKŪNAS T. Environ-mental genotoxicity and cytotoxicity in flounder (Platichthys flesus), herring (Clupea harengus) and Atlantic cod (Gadus morhua) from chemical munition dumping zones in the southern Baltic. Mar Environ Res. 96, 56, 2014.

27. ICES. Report of the ICES/BSRP Sea-going Workshop on Fish Disease Monitoring in the Baltic Sea (WKFDM), 5-12 December 2005. ICES CM 2006/BCC:02. 89, 2006.

28. AAS E., BEYER J., JONSSON G., REICHERT W.L., ANDERSEN O.K. Evidence of uptake, biotransformation and DNA binding of polyaromatic hydrocarbons in Atlantic cod and corkwing wrasse caught in the vicinity of an aluminium works. Mar Environ Res. 52, 213, 2001.

29. SHEEHAN D.Z., HRAPCHAK B.B. Theory and Practice of Histotechnology. Bettelle Press, Columbus 1980.

30. LANG T., WOSNIOK W., BARŠIENĖ J., BROEG K., KOPECKA J., PARKKONEN J. Liver histopathology in Baltic flounder (Platichthys flesus) as indicator of biological effects of contaminants. Mar Poll Bull. 53, 488, 2006.

31. GOODBRED S.L., GILLIOM R.J., GROSS T.S., DENSLOW N., BRYANT W.B., SCHOEB T.R. Reconnaissance of 17B-estradiol, 11-ketotestosterone, vitellogenin, and gonadal histopathology in common carp of United States streams: potential for contaminant-induced endocrine disruption. USGS U.S. Geological Survey, Open File Report 96-627, Sacramento, California 2007.

32. DREVNICK P.E., ROBERTS A.P., OTTER R.R., HAMMERSCHMIDT C.R., KLAPER R., ORIS J.T. Mercury toxicity in livers of northern pike (Esox lucius) from Isle Royale, USA. Comp Biochem Physiol C Tox Pharm. 147, $331,2008$.

33. HALLETT C.S., VALESINI F.J., CLARKE K.R., HESP S.A., HOEKSEMA S.D. Development and validation of fish-based, multimetric indices for assessing the ecological health of Western Australian estuaries. Estuar Coast Shelf Sci. 104, 102, 2012.

34. BROOKS M.L., FLEISHMAN E., BROWN L.R., LEHMAN P.W., WERNER I., SCHOLZ N., MITCHELMORE C., LOVVORN J.R., JOHNSON M.L., SCHLENK D., DRUNICK S., DREVER J.I., STOMS D.M., PARKER A.E., DUGDALE R. Life histories, salinity zones, and sublethal contributions of contaminants to pelagic fish declines illustrated with a case Study of San Francisco Estuary, California, USA. Estuar Coasts 35, 603, 2012.

35. BORJA A., BRICKER S.B., DAUER D.M., DEMETRIADES N.T., FERREIRA J.G., FORBES A.T., 
HUTCHINGS P., JIA X., KENCHINGTON R., MARQUES J.C., ZHU C. Overview of integrative tools and methods in assessing ecological integrity in estuarine and coastal systems worldwide. Mar Poll Bull. 56, 1519, 2008.

36. LEHTONEN K.K., SCHIEDEK D. Monitoring biological effects of pollution in the Baltic sea: neglected - but still wanted? Mar Poll Bull. 53, 377, 2006.

37. BROEG K., LEHTONEN K.K. Indices for the assessment of environmental pollution of the Baltic Sea coasts: integrated assessment of a multi-biomarker approach. Mar Poll Bull. 53, 508, 2006.

38. KAMMANN U., LANG T., WOSNIOK W. Biological effects monitoring in marine research. Env Sci Eur. 24, 1, 2012.

39. LEHTONEN K.K., SUNDELIN B., LANG T., STRAND J. Development of tools for integrated monitoring and assessment of hazardous substances and their biological effects in the Baltic Sea. Ambio 43, 69, 2014.

40. KOPECKA J., LEHTONEN K.K., BARŠIENE J., BROEG K., VUORINEN P.J., GERCKEN J., PEMPKOWIAK J. Measurement of biomarker levels in flounder (Platichthys flesus) and blue mussel (Mytilus trossulus) from the gulf of Gdańsk (southern Baltic). Mar Poll Bull. 53, 406, 2006.

41. LINDEROTH M., HANSSON T., LIEWENBORG B., SUNDBERG H., NOAKSSON E., HANSON M., ZEBÜR Y., BALK L. Basic physiological biomarkers in adult female perch (Perca fluviatilis) in a chronically polluted gradient in the Stockholm recipient (Sweden). Mar Poll Bull. 53, 437, 2006.

42. HANSSON T., SCHIEDECK D., LEHTONEN K.K., PEKKA J., LIEWENBORG B., NOAKSSON E., TJÄRNLUND U., HANSON M., BALK L. Biochemical biomarkers in adult female perch (Perca fluviatilis) in a chronically polluted gradient in the Stockholm recipient (Sweden). Mar Poll Bull. 53, 451, 2006.

43. VUORINEN P.J., KEINÄNEN M., VUONTISJÄRVI H., BARŠIENĖ J., BROEG K., FÖRLIN L., GERCKEN J, KOPECKA J., KÖHLER A., PARKKONEN J., PEMPKOWIAK J., SCHIEDEK D. Use of biliary PAH metabolites as a biomarker of pollution in fish from the Baltic. Mar Poll Bull. 53, 497, 2006.

44. NAPIERSKA D., BARŠIENĖ J., MULKIEWICH E., PODOLSKA M., RYBAKOVAS A. Biomarker response in flounder Platichthys flesus from the Polish coastal area of the Baltic Sea and applications in biomonitoring. Ecotox. 18, 846, 2009.

45. SCHIEDEK D., BROEG K., BARŠIENĖ J., LEHTONEN K.K., GERCKEN J., PFEIFER S., VUONTISJÄRVI H., VUORINEN P.J., DEDONYTE V., KÖHLER A., BALK L., SCHNEIDER R. Biomarker response as indication of contaminant effects in blue mussel (Mytilus edulis) and female eelpout (Zoarces viviparus) from the southwestern Baltic Sea. Mar Poll Bull. 53, 387, 2006.

46. DABROWSKA H., OSTASZEWSKA T., KOMASZEWSKI M., ANTONIAK A., NAPORA-RUTKOWSKI Ł., KOPKO O., LANG T., RICKE N., LEHTONEN K.K. Histopathological, histomorphometical, and immunocytochemical biomarkers in flounder (Platichthys flesus) from the southern Baltic sea. Ecotox Environ Safety 78, 14, 2012.

47. STENTIFORD G.D., LONGSHAW M., LYONS B.P., JONES G., GREEN M., FEIST S.W. Histopathological biomarkers in estuarine fish species for the assessment of biological effects of contaminants. Mar Environ Res. 55, 137, 2003.

48. LANG T., WOSNIOK W., BARŠIENĖ J., BROEG K., KOPECKA J., PARKKONEN J. Liver histopathology in Baltic flounder (Platichthys flesus) as indicator of biological effects of contaminants. Mar poll Bull. 53, 488, 2006.

49. FRICKE N.F., STENTIFORD G.D., FEIST S., LANG T. Liver histopathology in Baltic eelpout (Zoarces viviparous) - a baseline study for use in marine environmental monitoring. Mar Environ Res. 82, 1, 2012.

50. DAVIES I.M., VETHAAK A.D. Integrated marine environmental monitoring of chemicals and their effects. ICES Cooperative Research Report 315, 277, 2012.

51. BOGOVSKI S., LANG T., MELLERGAARD S. Histopathological examinations of liver nodules in flounder (Platichthys flesus L.) from the Baltic Sea. ICES J Mar Sci. 56, 148, 1999.

52. KANNAN K., FALANDYSZ J. Butyltin residues in sediment, fish, fish-eating birds, harbour porpoise and human tissues from the Polish coast of the Baltic Sea. Mar Poll Bull. 34, 203, 1997.

53. FALANDYSZ J., STRANDBERG B., STRANDBERG L., RAPPE C. Tris (4-chlorophenyl) methane and Tris (4-chlorophenyl) metanol in sediment and food webs from the Baltic south coast. Environ Sci \& Tech. 33, 517, 1999.

54. ZERIHUN M., COLQUOUN D.J., POPPE T.T. Experimental mycobacteriosis in Atlantic cod, Gadus morhua L. J Fish Dis. 35, 365, 2012.

55. ALFJORDEN A., JANSSON E., JOHANSSON K.E. A systemic granulomatous inflammatory disease in wild Atlantic cod, Gadus morhua associated with a bacterium of the genus Francisella. Disease interactions and pathogen exchange between farmed and wild aquatic animal populations - a European network. Newsletter 44.; VESO, Norway, available at: Www. DIPNET, 2006.

56. NYLUND A., OTTEM K.F. Francisellosis a new cod ( $G a-$ dus morhua) disease caused by Francisellan. sp. Disease Interactions and Pathogen Exchange between farmed and wild aquatic animal populations - a European network. Newsletter 45. 2006; VESO, Norway, available at: www. DIPNET, 2006.

57. W6PDMO Report, ICESCM 2010/SSGHIE:02, PG. 6, 2010.

58. GJESSING M.C., INAMI M., WELI S.C., ELLINGSEN T., FALK K., KOPPANG E.O., KVELLESTAD A. Presence and interaction of inflammatory cells in the spleen of Atlantic cod, Gadus morhua L., infected with Francisella noatunensis. J Fish Dis. 34, 687, 2014.

59. HEMMINGSEN W., MACKENZIE K. The parasite fauna of the Atlantic cod, Gadus morhua L. Adv Mar Bio. 40, 1, 2001.

60. MACKENZIE K., KALAVATI C., GAARD M., HEMMINGSEN W. Myxosporean gall bladder parasites of gadid fishes in the North Atlantic: their geographical distributions and an assessment of their economic importance in fisheries and mariculture. Fish Res. 76, 454, 2005.

61. FEIST S.W. Myxozoan Diseases. In: Fish Diseases, Volume 2 (ed. by J.C. Eiras, H. Segner, T. Wahli \& B.G. Kapoor) 613, Science Publishers, Enfield NH, 2008.

62. PAPERNA I. Digenea (Phylum Platyhelminthes). In: Fish Diseases and Disorders, Vol. 1, Protozoan and Metazoan Infections (ed. by P.T.K. Woo), 329. CABI Publishing, New York, USA. 1999.

63. BUCHMANN K., KANIA P. Emerging Pseudoterranova decipiens (Krabbe, 1878) problems in Baltic cod, Gadus morhua L., associated with grey seal colonization of spawning grounds. J Fish Dis. 35, 861, 2012.

64. HAARDER S., KANIA P.W., GALATIUS A., BUCHMANN K. Increased Contracaecum osculatum infection in Baltic cod (Gadus morhua) livers (1982-2012) associated with increasing grey seal (Halichoerus gryphus) populations. J Wildlife Dis. 50, 537, 2014. 
65. NADOLNA K., PODOLSKA M. Anisakid larvae in the liver of cod (Gadus morhua) L. from the southern Baltic Sea. J Helminthol. 88, 237, 2014.

66. BULLARD S.A., OVERSTREET R.M. Digeneans as enemies of fishes. In: Fish Diseases, Volume 2 (ed. by J.C. Eiras, H. Segner, T. Wahli \& B.G. Kapoor) 817, Science Publishers, Enfield NH, 2008.
67. UNGER P., KLIMPEL S., LANG T., PALM H.W. Metazoaan parasites from herring (Clupea herrengus L.) as biological indicators in the Baltic Sea. Acta Parasitol. 59, 518, 2014.

68. MC CORMICK J.H., STOKES G.N., HERMANUTZ R.O. Oocyte atresia and reproductive success in fathead minnows (Pimephales promelas) exposed to acidified hardwater environments. Arch Environ Contam Toxicol. 18, 207, 1989. 